\title{
NFC準拠ICタグを用いた 街路樹の情報管理システムの開発
}

\author{
矢吹 信喜 1 - 芦田 雄太 $2 \cdot$ 福田 知弘 $3 \cdot$ 道川 隆士 4 \\ 1フェロー会員 大阪大学教授 大学院工学研究科 環境・エネルギー工学専攻 \\ （干565-0871 大阪府吹田市山田丘2-1） \\ E-mail: yabuki@see.eng.osaka-u.ac.jp \\ 2非会員 元大阪大学大学院工学研究科 環境・エネルギー工学専攻 博士前期課程 \\ 3正会員 大阪大学准教授 大学院工学研究科 環境・エネルギー工学専攻 \\ 4非会員 大阪大学特任助教 環境イノベーションデザインセンター
}

\begin{abstract}
本稿では，NFC (Near Field Communication)を用いて，街路樹診断や市民を対象とした樹木情報の提供を 可能とする情報管理システムを提案する。提案システムは, 各街路樹にNFC準拠ICタグを設置し，ユーザ が所有するNFC対応端末と通信して街路樹の情報を閲覧, 編集する。データのやり取りはインターネット を通してシームレスに行われるため，提案システムは効率的に街路樹の診断などの作業を行うことを可能 にする。本研究では，樹木管理システムおよび樹木情報提供システムを開発し，樹木医，学生による実証 実験を通して本システムの有用性を検証した。本研究では, 実用化において問題となるICタグの設置方法 に関しても検討した。
\end{abstract}

Key Words : roadside tree diagnosis, NFC (Near Field Communication), tablet terminals

\section{1. 緒論}

街路樹は，道路に沿って植えられた樹木である．街路 樹は, $\mathrm{CO} 2$ 吸収固定効果やヒートアイランド現象緩和効 果に加え，景観向上効果，心理的効果，生態系誘致効果 などの多様な環境改善効果をもつことから，都市部への 積極的な導入が進められている．国土交通省が2007年に

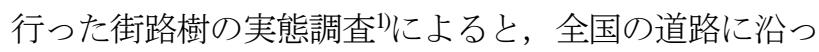
て植えられている高木の街路樹の数は約667万本である. これは，1987年における371万本の約1.8倍であり，この 20年間で街路樹の整備が進んできていることがわかる.

街路樹の整備が進むに従い，その維持管理が大きな問 題となっている. 街路樹の周りには, 電線, 電柱, 照明 灯，標識，看板・広告などの空中施設，ガス管・水道管 に代表される埋設物，共同溝などの地下施設が存在し， これらとの競合のために，街路樹は様々な生育阻害を受 ける．また，枝や幹の強剪定や根上がりなども頻繁に見 られる．更に，道路からの排気ガスや粉鹿といった負荷 要素も合わさることから，街路樹は樹木にとって劣悪な 環境で生育しているといえる.この環境から受ける街路 樹への影響を放置していると, キノコや病虫害の発生, 枝枯れ，幹の空洞化，腐朽の進行などにより樹勢（樹木
の生育状態）が衰退する。この結果，街路樹の有する機 能が発揮されなくなるだけでなく, 台風などの災害が発 生した際に倒木被害をもたらす可能性がある.

街路樹の維持管理の問題を解決するためには，定期的 な診断による生育状況の観察および長寿命化が必須であ る. 街路樹診断で重要となるのは，専門家である樹木医 の勘や経験に依存しない検査方法の確立とデータを蓄積 することである．検査方法については，Mattheckが提案 したVTA (Visual Tree Assessment) 法2)が有名である.VTA 法は，樹体内部の病気や腐朽などの欠陥を外観調査から 発見する手法である．VTA法は，専門家の勘や経験のみ に依存せず，共通の手順に従って，科学的かつ体系的に 診断され，樹木の健康状態や今後の処置計画まで判断さ れることが大きな特徴である. データの追跡は, 前回の 診断結果の差分から街路樹の異变を検出寸るために利用 する.

街路樹診断を客観的に行う手法が存在する一方で，現 場での導入が進んでいないという問題がある。これは, 診断業務が紙ベースのカルテによって行われていること により，写し間違いなど，データの信頼性に問題がある ためである.また街路樹の伐採や植え替えの結果，固体 識別ができなくなるという問題もある. 
この問題点を解決するためには，情報技術を用いたヒ ユーマンエラーの余地がないシステムの利用が重要であ る. 矢吹らは，街路樹診断の計画的な実施による継続的 な管理を可能とするために，ICタグとPDA(Personal Digital Assistant)を用いたVTA法に基づく街路樹診断支援システ ムを開発した ${ }^{3)}$.しかし，ICタグの規格や携带端末の一 般性の低さから汎用性の点で問題が残る。

本論文では，NFC(Near Field Communication) 準拠ICタグ とタブレット端末を用いて街路樹診断の効率化を図る街 路樹情報管理システムを提案する．NFCとは， $13.56 \mathrm{MHz}$ の周波数を利用する通信距離 $10 \mathrm{~cm}$ 程度の近距離無線通 信技術の国際標準規格)である．NFCは，市販されてい るスマートフォンの多くに搭載されていることから，実 用化が簡単である特長を持つ. 本研究では，このNFCを 搭載した端末を各街路樹に設置したICタグとの通信に利 用する.

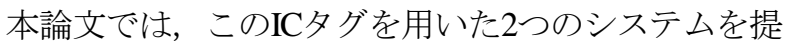
案する.1つは, 街路樹診断システムである.これは, 従来の街路樹診断で問題となっていたデータの追跡，写 し間違いなどの問題点を解決する．もう1つは，市民を 対象とした樹木情報提供システムを提案する．樹木をは じめとした植物の種類は多岐に渡り，専門家以外では区 別することが難しい，提案システムを利用することで市 民の緑に対する理解を向上させることが可能となる．ま た，本論文では，ICタグの設置方法に関しても検討を行 い，利用者にとって使いやすい設置方法も合わせて提案 する.

\section{2. 既往研究}

\section{(1) 街路樹診断}

街路樹診断とは，樹木医が行う管理作業であり，活力 の衰えた樹木や倒木・幹折れなどの危険性がある樹木を 早期に発見して，適切な処置を施すことにより，樹木の 健全な育成を図り，樹木による事故を防止することを目 的とする 5. 街路樹診断は, 街路樹管理におけるその他 の委託作業（緑地保護管理，剪定など）において樹木の 異常が発見された場合に実施され，「初期診断」「外観 診断」「精密診断」からなる. 図-1 に街路樹診断のフ ローを示す.

初期診断とは，街路樹診断において最初に行われる診 断で，倒木などの危険性の高い樹木を迅速に発見して適 切な処置を早期に行うとともに，外観診断の必要な樹木 を抽出するために実施される. 初期診断表の診断項目に 沿って異常の有無を記入し，被害状況，被害程度を記載 し，その結果に基づいて外観診断や処置の必要性を判定 する．樹木ごとの全体的な姿や周辺の樹木との関係を十

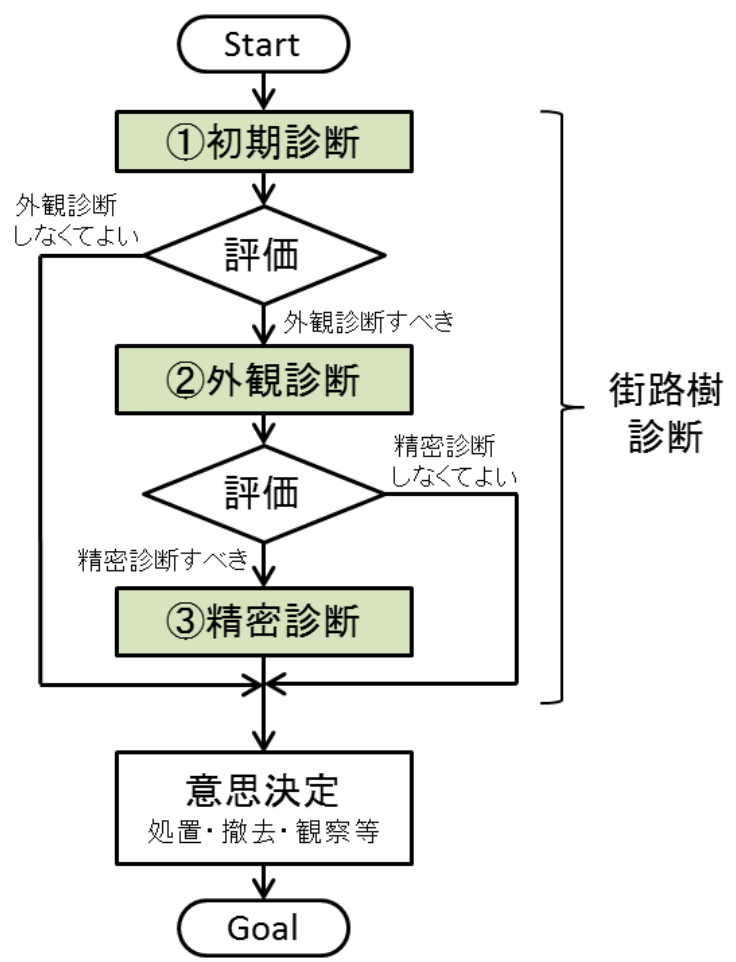

図-1 街路樹診断のフロー（文献5)をもとに作成）

分に把握して，何らかの症状によって異常を感じた場合 には，原因が特定できない場合でも記録して報告する.

外観診断とは，初期診断によって外観診断が必要とさ れた街路樹に対して行う診断で，樹木の外観の観察によ って，樹木内部の被害程度を診断するものである．街路 樹診断力ルテの診断項目に沿って活力診断及び部位診断 を行い，その診断結果に基づいて外観診断判定を行う。 外観診断は，樹木の今後の処置を決定し，事故を未然に 防ぐことにつながる重要な判定を行うことから，十分な 注意を払い，正確な診断を心がける必要がある．活力が 健全に見える樹木でも，樹幹内部や根株に極めて危険な 空洞や腐朽を内在している場合があることから，幹の形 状などを注意深く観察し，また，打診などにより精密診 断を必要とする樹木を判断する.

精密診断とは，外観診断によって精密診断が必要とさ れた街路樹に対して行う診断である。外観からは分から ない腐朽の程度や大きさを調べるために，樹木診断機器 を用いて腐朽状態や腐朽量を測定し，腐朽や空洞の程度 を数值的に把握し，客観的なデー夕に基づき判定を行う。 外観診断の結果を確認し, 診断部位や樹木の立地条件及 び樹木診断機器の特性などを踏まえて，適切な使用機器 を選定する.

街路樹診断実施後の診断結果は, 行政指定のフォーマ ットに従い，電子データとして管理事務所に提出すると ともに，管理データベースである「街路樹診断システ 
ム」に登録する，ただし，初期診断に関しては，紙べー スの診断カルテの提出のみとなっており, 電子的に記録 されていないのが現状である.

\section{(2) 街路樹診断に関する既往研究}

街路樹管理の非効率性, データ蓄積不足という課題に 着目し, 開澤ら けは, 高解像度衛星データを活用したリ モートセンシングによって街路樹の健全度評価を行う管 理手法を提案している. この手法では, 植樹帯の広さや 陽当たりによってある範囲での同樹種の街路樹間の活性 度の違いがあることを認識することはできるが，街路樹 1 本ずつの管理に適用することはできない，適切な街路 樹管理のためには，個別の街路樹診断は不可欠であるた め, この手法だけでの管理では不十分である.また, 佐々木ら7も同様の課題に着目し, GIS や診断ロボット を利用した街路樹管理支援システムを提案している。 こ れは，人工衛星や航空機画像から広域的に街路樹のモ二 タリングを行いながら, 樹木の空洞化などの詳細な調査 は，診断ロボットによるセンシングを行うというシステ ムである. しかし，ロボットが空間内で樹木を認識する アルゴリズムの高精度化や, 病虫害などを自動的に診断 する技術の開発など，提案を具現化させるにはさまざま な課題が残っており実用上の問題点は多い.

矢吹ら ${ }^{3}$ は, 街路樹診断の計画的な実施による継続的 な管理を可能とするために，IC タグと PDA を用いた VTA 法に基づく街路樹診断支援システムを開発した. このシステムでは，IC タグを樹木に設置し，PDA で IC タグの固有 ID を読み取ることで個体識別性を向上させ ている. また, 街路樹診断の際に通常紙に記録される診 断データを PDA 内に記録することで, 診断データの収 集・蓄積を効率化・確実化させている，しかし，診断デ 一タを端末に入れて持ち歩く必要があり, 効率性などに 改善の余地があることや, IC タグの通信規格の一般性 の低さ，携帯端末の不適切さ，IC タグの設置手法の検 討不足などの課題がある.

実在する樹木と照らし合わせながら樹木情報を得る方 法に樹木板があるが，情報量が少ないといった課題があ る. この課題を解決する方法として, QR(Quick Response) コード付きの樹木板が開発されている ${ }^{8) か ゙ ， Q R ~ コ ー ト ゙ ~}$ は污れや傷に弱いという課題がある. QR コードの課題 を解決する方法として RFID タグと PDAを利用する方法 が開発されている9. しかし，PDAの一般性が低いため, 利用者は植物園などの限られた空間で端末を借りなけれ ばならず，限定的な利用にとどまっている．また，近年 のスマートフォンの普及から, 花や樹木の特徵を入力す ることで考えられる候補を一覧することができる Web サービスを利用することで樹種の特定と情報の取得を行 う方法もある（例えば資料 ${ }^{10)}$ ) が，正確な樹種特定が

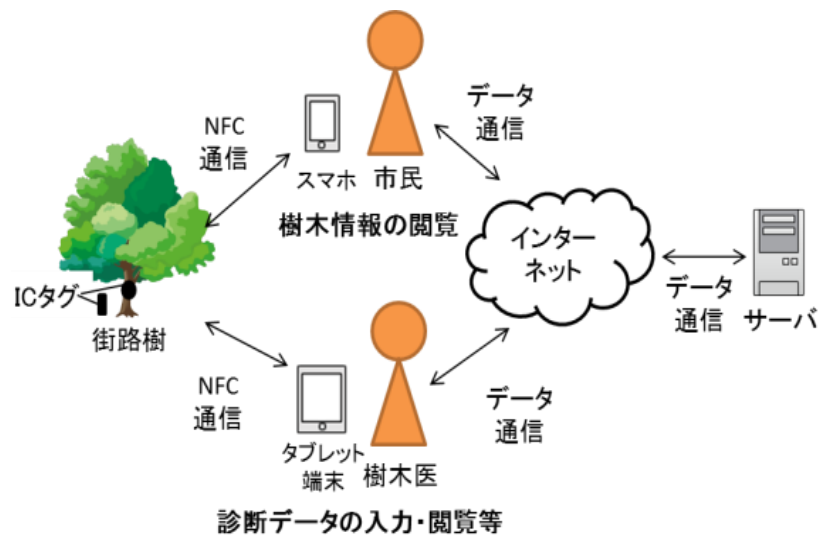

図-2提案システムの概要

難しく, 調べるために手間がかかるという課題がある. また，葉を撮影して樹木を特定するスマートフォンアプ リも開発されている ${ }^{11}$ が，葉がなければ使用できず，カ メラを起動する手間が必要という課題がある.

\section{3. 提案システム}

本論文で提案する街路樹診断システムと樹木情報提供 システムは，樹木医と市民をそれぞれ対象としている点 は異なるが，システムの枠組みは同じである. 提案シス テムは, 街路樹にNFCに準拠したICタグを設置し，タブ レットを用いて固有情報を取得し，サーバーと通信して 情報を取得, 編集するシステムである. 図-2に提案シス テムの概要を示す．次節以降で各システムの詳細を述べ るとともに，ICタグの設置方法について述べる.

\section{(1) 街路樹診断システム}

街路樹診断支援システムは, 個々の街路樹に NFC 準 拠 IC タグを設置し, NFC 搭載のタブレット端末によっ て街路樹診断を支援するものである.

本システムは, 最新の街路樹診断マニュアルである東 京都のマニュアルらに準拠して開発する. また，対象と する街路樹診断は，「初期診断」と「外観診断」である。 初期診断と外観診断は，樹木の部位ごとに診断項目があ り, 全体として入力項目は多い. 特に, 外観診断は詳細 な診断が求められるため, 入力項目は膨大である. 一方, 精密診断は, 診断機器を用いて行う街路樹診断であり, 診断機器の出力結果の入力が主である. 以上のことから, 現地での診断支援ツールとして，初期診断と外観診断を 対象とすることとする.

街路樹診断システムが提供する機能は4つある．樹木 情報登録・表示機能，前回診断データ閲覧機能，新診断 データ・入力保存機能, ICタグの再登録機能である.

樹木情報登録・表示機能は, 毎回の診断によって変化 


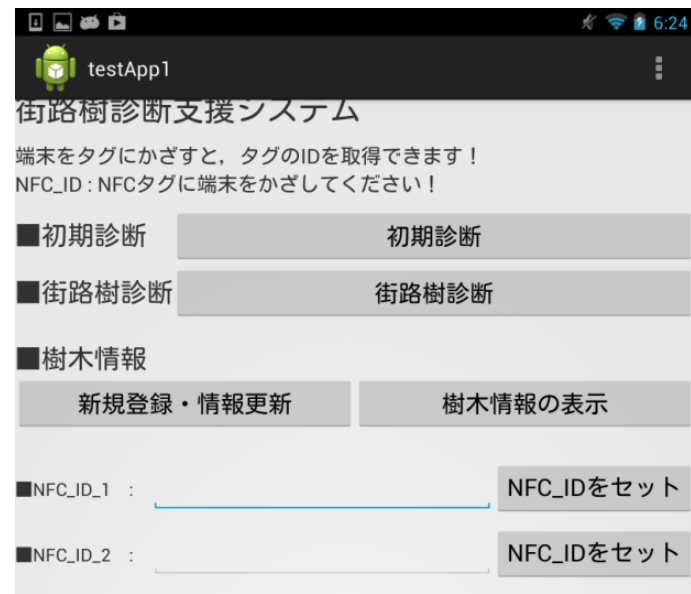

図-3樹木情報登録画面
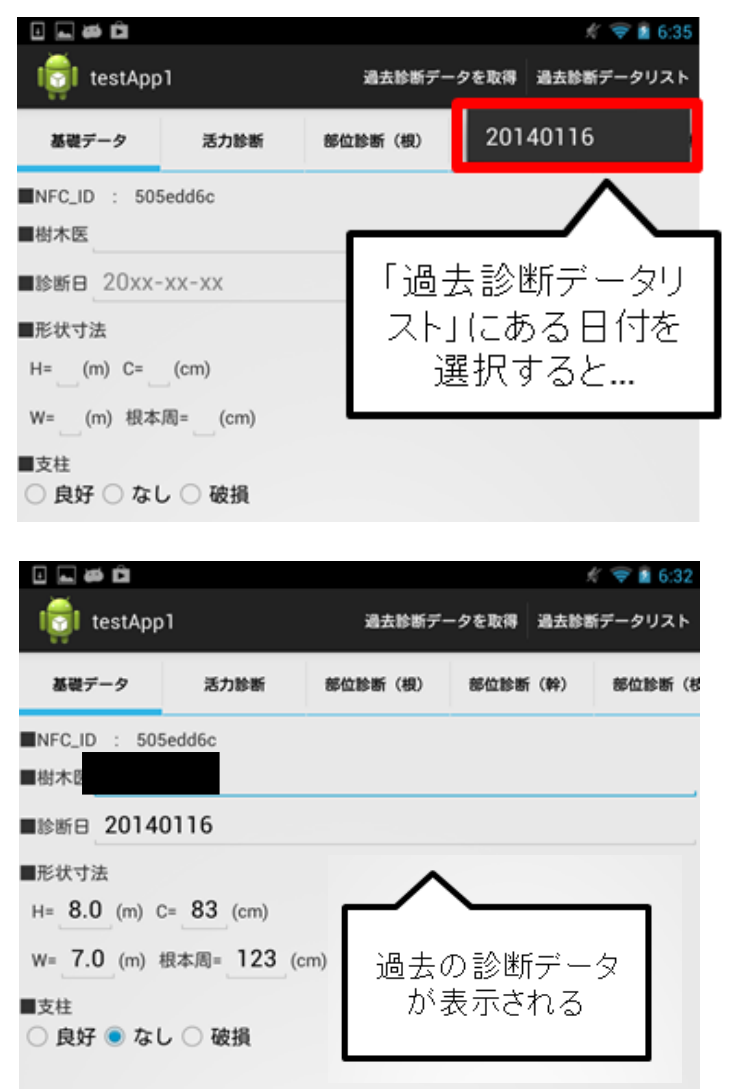

図-4 前回診断データ閲覧機能画面

しない街路樹固有の情報（樹木情報）をICタグの固有ID とひも付けてサーバーに登録する機能である. 登録でき る樹木情報は，街路樹の管理事務所，植栽されている路 線名，住所，樹種名，樹木番号，植栽形態，緯度，経度， 距離標（キロポスト）である。登録された樹木情報は， ICタグのタグIDをもとにサーバーから検索し，端末上で 閲覧することができる．また，樹木の移植などで樹木情 報を更新する必要がある場合は，更新する項目を記入し，

「新規登録・情報更新」ボタンを押寸ことで，データの 更新をすることができる．図-3に樹木情報の登録画面， 登録された樹木情報の表示結果を示す。

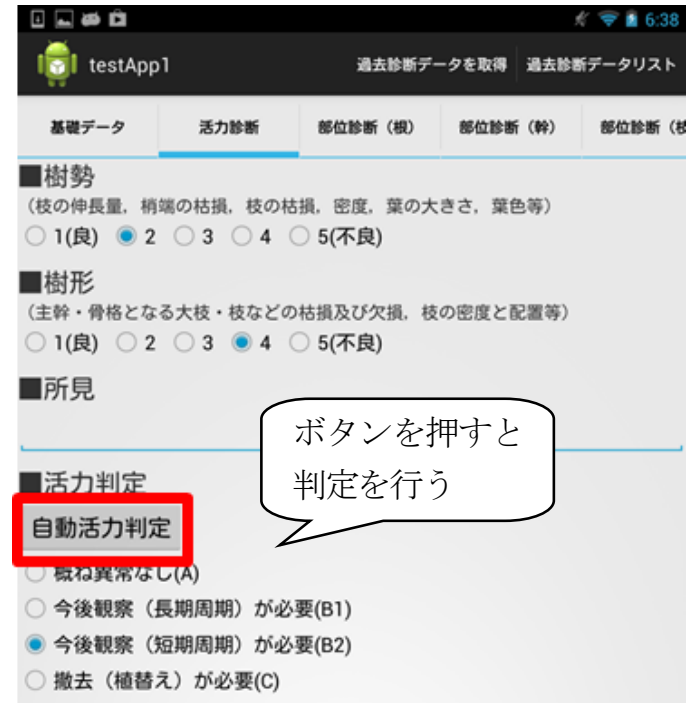

図-5判定の自動処理機能画面

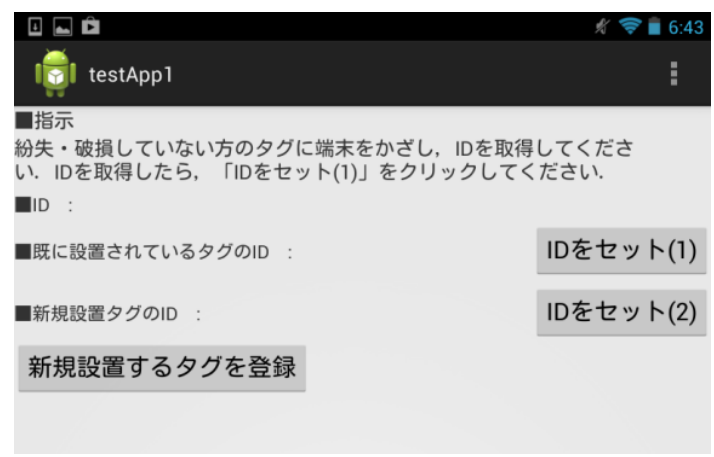

図-6IC タグの再登録画面

前回診断データ閲覧機能は，サーバー内に前回診断デ ータがある場合，ICタグの固有IDをもとに前回診断デー タを検索し，端末上に表示する機能である．本機能によ って，診断者は大量のカルテを持ち歩かずとも，前回診 断を参考にしながら新規診断を行うことができる．図-4 に，前回診断データ閲覧機能の使用例を示寸.

新規診断データ入力・保存機能は，タブレット端末に 一連の街路樹診断データを入力し，「サーバーに保存」 ボタンを選択することで，サーバーに診断データを保存 する機能である．屋外での作業であることを考慮し，自 由記入項目をドロップダウン化し，ラジオボタンやチェ ックボックスを使用して簡易な操作によって診断データ の入力ができる．また，計算処理や判定処理で自動化可 能な部分を自動化することにより，診断効率の向上を図 っている. 図-5に本機能における判定の自動処理機能を 示寸.

ICタグの再登録機能は，樹木に設置していたICタグが 破損・紛失した場合を想定し，新たなICタグを再設置す る際に，再設置するICタグと過去の診断データをひも付 けるための機能である. データのひも付けは, 設置して いたICタグが全て破損・紛失している場合は樹木番号を 


\section{httptest}

樹木情報を表示します！

<名称 $>$

ケヤキ (欅，学名：Zelkova serrata，別名：ツ キ(槻) )

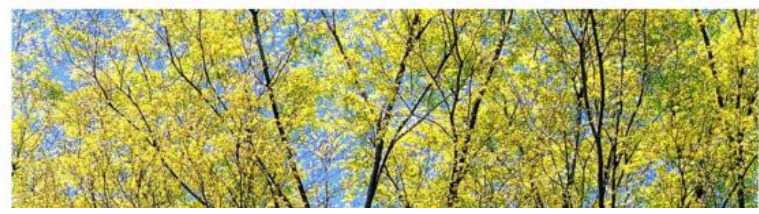

図-7樹木情報提供機能画面
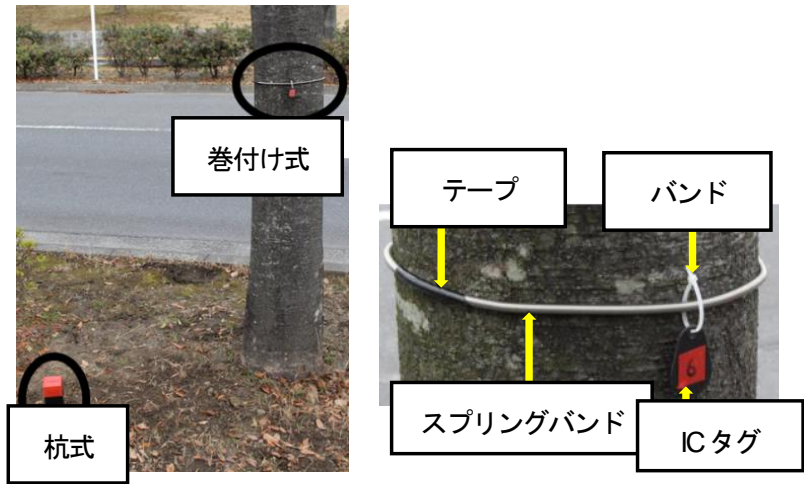

図-8＼cjkstart樹木識別のための IC タグの設置

利用してひも付けを行う。一方，設置していたICタグが 1つでも破損・紛失せずに残っている場合は，残ってい るICタグのIDを利用してひも付けを行う．入力画面の指 示に従い, ICタグの読み込み, データの入力を行うこと で，現地で容易に再登録ができる．図-6に，ICタグの再 登録画面を示す。

\section{（2）樹木情報提供システム}

樹木情報提供システムは，個々の街路樹に NFC 準拠 IC タグを設置し， NFC 搭載のスマートフォンやタブレ ット端末を IC タグにかざすことによって樹木に関する 情報を取得できるシステムである.

ユーザはアプリケーションをインストールした状態で, 樹木に設置されている IC タグに端末をかざすことで固 有 ID を取得する. 取得された固有 IDは，サーバーに送 られる. サーバーでは，固有 ID をもとにその樹木に関 する Web ページ（樹木情報ページ）が検索され，端末 にそのページを送信することで，ユーザは樹木情報を閲 覧することができる（図-7）。樹木情報ページには，文 献 12), 13), 14)を参考に，「樹種名」，「形態的特徽」「分布， 原産地」などの情報を掲載した。また，その樹種の Wikipedia のページヘのリンクや Google 検索へのリンク があり，ユーザはさらなる情報の取得ができる.

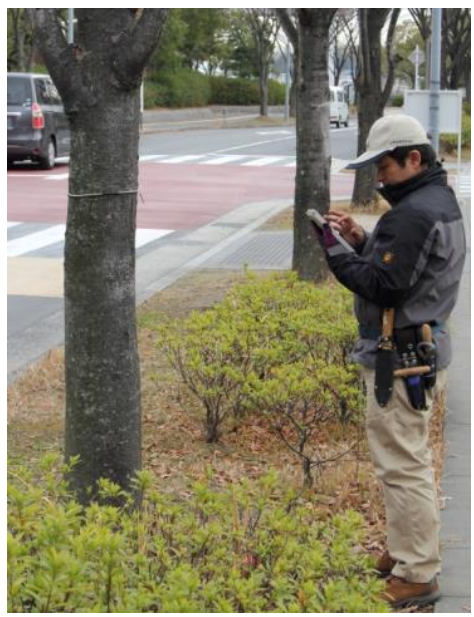

図-9＼cjkstart街路樹診断実験の様子

\section{(3) ICタグ設置方法の開発}

提案システムにおいて，IC タグの設置箇所の検討は， 利用者の情報アクセスのしやすさを左右する重要な問題 である．樹木情報を表示する方法として，樹木の名前等 が記載されたプレート（樹木板）が樹木のそばに設置さ れているが，本研究では，それを参考に IC タグの設置 方法について検討する.

IC タグの設置条件として，利用者にとって IC タグが アクセスしやすいという利便性のほかに，景観にできる だけ影響を与えない，自然環境の変化やいたずらなど長 期間利用に対する而性，樹木への非侵襲性などが挙げら れる. 現在，IC タグの設置方法として，縁石上や，杭， 看板, 支柱に設置する方法, 直付けする方法, 樹木に埋 め込む方法, 吊り下げる方法, 幹に巻きつける方法など が考えられる. しかし，設置条件を全て満足する設置方 法は存在しない.

本研究では，幹に巻きつける方法（巻付け式）と杭を 打ちつける方法（杭式）を組夕合わせた方法を提案する. 巻付け式を採用した理由は，最もアクセスがしやすいた めである. 巻付け式で問題となる樹木への侵襲性は，幹 にスプリングバンドを巻き付ける方式を採用することで 軽減できる。また，複数方式を併用する理由は，IC タ グの盗難, 紛失のリスクを分散させるためである. 1 つ だけの場合，故障したときに，対象となる IC タグの特 定に時間がかかるが，複数設置することでその時間を大 幅に削減する.もう 1 つ方式に杭式を利用したのは, 景観への影響を最小限に抑えるためである，また，樹木 の周りにワイヤを 1 周させることで，杭の盗難防止を図 る.

\section{4. 実験結果}

提案したシステムの有用性を評価するため，実在する 


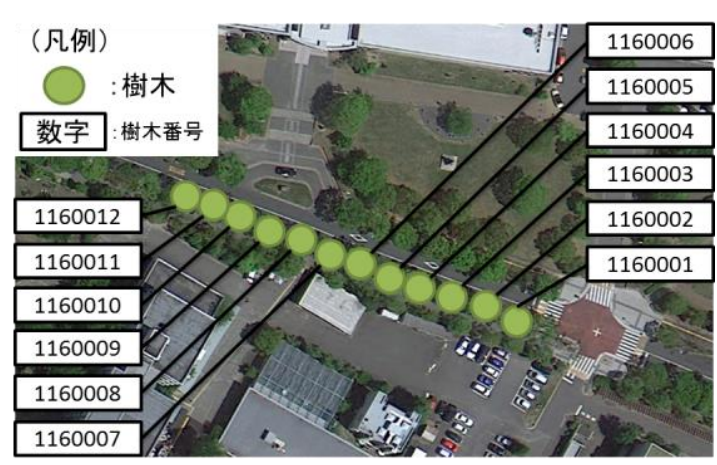

図-10 街路樹診断システムの実験環境

街路樹を対象とした実証実験を行った。実験に使用し たサーバーは，UNIX環境にApache (Ver. 1.3.42), MySQL (Ver.5.5)，PHP (Ver.5.4.22)を用いて構築した. クライアン トのタブレット端末は, Google社のNexus7である.クラ イアント側のアプリケーションはJavaで作成した. アプ リケーションは，あらかじめタブレット端末にインスト 一ルして被験者に手渡して実験を行った，以下，それぞ れのシステムの実験結果について述べる.

\section{(1) 街路樹診断システムの評価}

街路樹診断システムの実験は，2014年1月16日に大阪 大学吹田キャンパス中央通りで行った。調查対象は，実 験場所にあるケヤキ12本である．被験者は，樹木医資格 を保有する40代男性1名である. 被験者は，月 $1 \sim 3$ 回 程度の樹木の診断業務を行っており，十分な経験を有し ている．また被験者は，スマートフォンの操作には慣れ ており，本実験を行う上で支障はない，図-9に実験の様 子を示す.

実験は，実験場所にある12本の樹木に対して，図-10 に示寸ような樹木番号を設定し，以下の手順で診断業務 を行うとともに作業時間を計測した。

1. No.1160001 - 1160003の樹木に対して, 提案システム を用いた外観診断を実施

2. No.1160004-1160006の樹木にに対して，手書きによ る外観診断を実施

3. No.1160007-1160009の樹木に対して, 提案システム を用いた初期診断を実施

4. No. 1600010-1160012の樹木に対して手書きによる初 期診断を実施

手書きによる診断については，現地での作業時間のほか に事務所にて書き写すのに要した時間を聞き取り，作業 時間に追加した.

各実験に要した作業時間を表-1に示す．No. 1160009に 対する初期診断で通信エラーによる失敗が確認できたた
表-1 街路樹診断実験結果

\begin{tabular}{|c|l|c|c|c|}
\hline \multirow{2}{*}{ 種類 } & 方法 & $\begin{array}{c}\text { 現場での } \\
\text { 平均時間 }\end{array}$ & $\begin{array}{c}\text { 事務所での } \\
\text { 作業時間 }\end{array}$ & 合計 \\
\hline \multirow{2}{*}{ 外観 } & 提案手法 & 12.57 & 0.00 & 12.57 \\
\cline { 2 - 5 } & 手㶳き & 8.38 & 36.50 & 44.88 \\
\hline \multirow{2}{*}{ 初期 } & 提案手法 & 4.57 & 0.00 & 4.57 \\
\cline { 2 - 5 } & 手書き & 3.37 & 7.00 & 10.37 \\
\hline \multicolumn{2}{|r}{} & \multicolumn{2}{|c}{ (単位 : 分) }
\end{tabular}

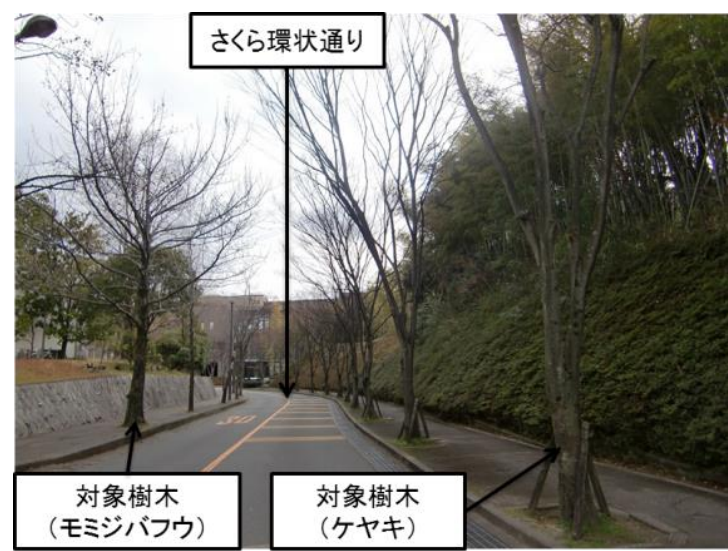

図-11 樹木情報提供システムの実験環境

め，計測が行えなかった．確認のため，後日同一場所で 著者らによる実験を行った結果，一連の作業を行えたこ とを確認した．以上のことから，失敗の原因は，通信環 境が不安定だったことによるものと考えられる. そのた め, No.1160009については，作業時間からは除外した. それ以外の樹木については問題なく作業を行うことがで きた．表-1から，現地での作業時間は，提案システムを 利用するよりも従来システムを利用したほうが早いこと がわかる。これは，システムの習熟度のほかに提案シス テムのほうが現地で行う作業が多いことが原因として考 えられる。しかし，事務所での作業も考慮した作業時間 は，提案システムのほうが短いことがわかった．特に外 観診断は，30分以上短縮できたことを確認した．これは， 診断作業を現地で全て終わらせることができるためだと 考えられる.

樹木医に対するヒアリングでは，ネットワークを介し て過去診断データを参照できること，診断結果や端末で 撮影した樹木の写真を簡単にデータベースにアップロー ドできることに対する評価が高かった．これは，従来の 紙べースの診断の欠点である紛失や書き写しのミスを提 案システムが解決していることに対寸る評価であり，予 想された効果が得られていることがわかる，また，IC夕 グを用いた固体識別に対しては，従来の写真，位置図に よる識別方法と比較して確実に識別できるという点で評 価が高かった。一方で，情報入力に関する使いやすさに 関して改善の余地があるという意見を得た。例えば, 

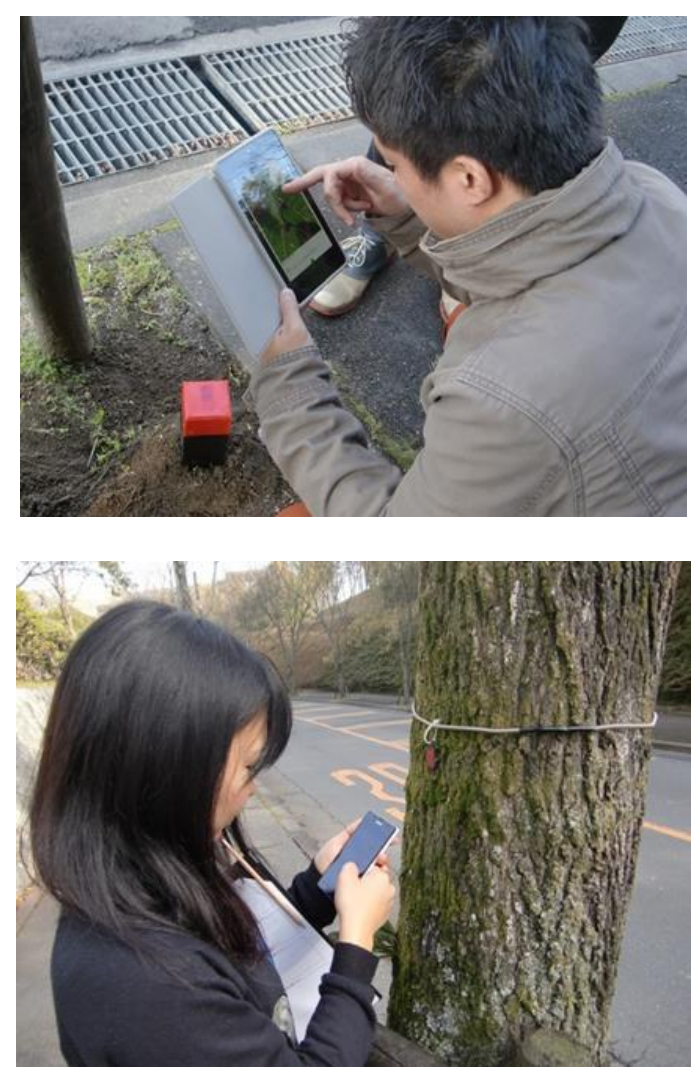

図-12 実験の様子

表-2アンケート結果

\begin{tabular}{|c|c|c|}
\hline \multirow{2}{*}{} & \multicolumn{2}{|c|}{ 全体 (N=26) } \\
\cline { 2 - 3 } & 平均値 & 標準偏差 \\
\hline 手軽さ & 4.462 & 0.796 \\
\hline 短時間で起動 & 4.654 & 0.551 \\
\hline 学習效果 & 4.462 & 0.570 \\
\hline 興味・関心の高揚 & 3.846 & 0.863 \\
\hline 緑化意識の高揚 & 3.115 & 0.847 \\
\hline 使用意欲 & 3.923 & 0.874 \\
\hline
\end{tabular}

「どの異常が」，「どの部位にあるか」などと情報入力 には一定の順番が想定される.しかし，実装したシステ ムではそのような画面構成になっていないことで入力の 手間が発生したとの指摘があった.

\section{（2）樹木情報提供システムの評価}

樹木情報提供システムの実験は，2014年1月31日から2 月3日にかけて大阪大学吹田キャンパスさくら環状通り で実施した（図-11）。対象樹木は，ケヤキとモミジバ フウの2本の街路樹である. 被験者は, 20 代の学生26名 （男性17名，女性9名）であり, 携帯端末の操作には習 熟していた.

実験は,アプリケーションをインストールした Android端末を被験者に渡し，実験目的，使用方法を説 明した後, 実際に利用してもらうことで行った. 図-12
に実験の様子を示す．実験後, アンケートに回答しても らい, システムを評価した. アンケートは, 手軽さ, 学 習効果，興味関心の効用など6項目に関して5段階(5: 好 評価, 1 低評価)で評価してもらった.

アンケートの評価結果を表-2に示寸. アンケート結果 から，「手軽さ」，「短時間で起動」，「学習効果」に ついて平均 4 点以上の得点を得られたことがわかり，提 案システムが手軽に短時間で樹木情報を閲覧でき，高い 学習効果が得られることがわかった. 実際に自由記述で も教育現場での利用に有用だとのコメントが得られた. 一方, 緑化意識の高揚という点は, ほぼ3点と低い結果 となった，自由記述のアンケートからは，主に画面構成， 内容に関する改善に関する指摘が多く, ユーザビリティ および情報提供内容については精査する必要がわかった。 また，樹木の高さなど樹木固有の情報の提供に対する必 要性を指摘したコメントが多かった.

\section{(3) ICタグ設置の評価}

ICタグ設置手法の評価は, 街路樹診断実験および樹 木情報提供システム実験時にヒアリングを行うことで行 った．被験者は樹木医1名および20代の学生26名である。 評価の結果, 巻付け式が, 杭打ち式よりも有効であると いう意見が多かった。これは, 杭打ち式が地表にあるこ とからアクセスがしづらいなどの問題点がある一方, 巻 付け式は，かざしやすい位置に設置されている点がよい との意見が多かった. しかし，巻打ち式はいたずらの対 象になりやすいことや，ICタグが景観を損ねているとの 指摘があった．これについては，今後も検討が必要であ る.

\section{5. 結論}

本論文では，NFC準拠Cタグを利用した街路樹に関す る情報管理システムを提案した. 提案システムは, 樹木 医を対象とした街路樹診断システムと市民を対象とした 樹木情報提供システムからなる. 各システムにおいて, ユーザは, 街路樹に設置されたICタグに手持ちの携帯端 末を近づけることで樹木を同定し，サーバーから情報を 取得し, 街路樹診断や樹木情報を取得する. また, IC夕 グの設置方法についても検討を行い, 巻付け式と杭打ち 式に併用方法を提案した. 害際にこれらのシステムを構 築し, 樹木医や学生などの一般人を対象とした実験を行 った結果, 従来の街路樹診断で問題となっていたデータ の蓄積に有用であるだけでなく, 植物への理解を促進す るシステムであることを確認した.

提案したシステムは, まだ試作段階であり, ユーザビ リティ向上や, ネットワークが不安定な箇所での対応な 
ど，実用化に向けて解決すべき問題は多い.また，より 大規模な環境で実験することで，ICタグを利用した提案 システムの有用性が顕著になることが予想されることか ら，より大規模な実証実験が必要である．ICタグの設置 についても，長期間にわたる設置実験等を通して，実用 上の問題点を検証することも今後の課題として挙げられ る。また，実験は20代の学生のみを対象としており，幅 広い年齢層を対象としていない，同様の実験を様々な年 齢層の市民に行うことを通して，システムの有用性を検 証することが今後求められる.

\section{参考文献}

1）国土交通省 国土技術政策総合研究所：「わが国の街 路樹 VI」, http://www.nilim.go.jp/lab/bcg/siryou/tnn/tnn 0506pdf/ks0506.pdf（2014.1.31 取得）

2) 東邦レオ株式会社：「樹木の健康診断（街路樹の外 観・精密診断）」, http://www.soil-doctor.jp/shindan/ (2014.2.1 参照)

3) 矢吹信喜, 菊重有輝, 福田知弘, 江端夢歌 : RFID 技 術とオントロジーを用いた街路樹管理支援システム の開発，土木学会論文集 F3（土木情報学）, Vol.68, No.1,pp.13-27, 2012.

4) トッパンフォームズ株式会社 : NFC の基礎知識と特 徵について, http://www.nfc-world.com/about/index.html, (2014.10.20 取得)
5) 東京都建設局公園緑地部：「平成 25 年度街路樹診断 マニュアル」, http://www.kensetsu.metro.tokyo.jp/koue n/gairojyu/hyoushi7-1/H25gairojyumanyuaru.pdf, （2014. 2.2 取得）

6) 開澤祐一, 藤井壽生, 山本満, 工藤勝輝 : 高解像度 衛星データを活用した街路樹管理手法に関する研究, 日本大学生産工学部学術講演会土木部会講演概要, 第 40 巻, pp.75-78, 2007.

7) 佐々木豊, 田島淳, 井上俊太, 鈴木正肚 : 街路樹管 理・診断ロボットを想定した仮想空間における樹木 認識, 東京農業大学農学集報, 第 52 巻, 第 1 号, pp. 33-38, 2007/

8) アボック社, http://www.aboc.co.jp/ （2014.2.2 参照）

9） ITpro：IC タグシステムで屋上庭園にある植物の情報 を提供, http://itpro.nikkeibp.co.jp/article/RFID/2006063 0/242227/（2014.2.2 参照）

10) 樹木検索 $く ん:$ http://www.tree-watching.info/kensaku/1t /kensakuA0.html (2014.2.2 参照)

11) Leafsnap : http://www.appbank.net/2011/05/11/iphone-ap plication/252315.php (2014.2.2 参照)

12) 福井希一, 栗原佐智子：「キャンパスに咲く花 阪 大吹田編」, 大阪大学出版会, 2008.

13) 平野隆久：「よくわかる樹木大図鑑」，永岡書店，2 007.

14）建設省都市局公園緑地課：「緑化樹木ガイドブッ ク」，財団法人建設物価調查会，2001.

\section{DEVELOPMENT OF MANAGEMENT SYSTEM FOR ROADSIDE TREES USING NFC COMPLIANT IC TAGS Nobuyoshi YABUKI, Yuta ASHIDA, Tomohiro FUKUDA and Takashi MICHIKAWA}

This paper introduces an information management system for roadside trees using NFC (Near Field Communication) compliant IC tags. Given roadside trees identified by the IC tags, our system enables to retrieve and to edit tree information by touching the IC tags with NFC compliant tablet devices. Since the devices are connected to the internet, our system can make a diagnosis efficiently. In this research, we developed two prototypes: tree diagnosis system for arborists and tree information retrieval system for citizens. In addition, we also discuss a method for installing IC tags. This paper also evaluates the systems by experiments by arborists and citizens. 